\title{
Environment agency panel to 'steer' research plans
}

Washington. Costel Denson, vice-provost for research at the University of Delaware, is to chair a Board of Scientific Counsellors set up by the research office of the Environmental Protection Agency (EPA) to advise it on its programmes and procedures.

The board, whose 15 members were nominated by laboratory directors of the Office of Research and Development (ORD), meets for the first time on 19 August.

EPA already has a Science Advisory Board, but its main purpose is to evaluate research after it is finished, according to ORD chief Robert Huggett. The new group will advise ORD on its research agenda and will help the office to set up procedures for peer review of outside grants as well as of its own laboratories and personnel.

But it will not duplicate any of the activities of the Science Advisory Board. That way, says Huggett, the group recommending what research the office should be pursuing will not be responsible also for reviewing the products of that research.

In the two years since Huggett arrived at EPA, the ORD has made a high-profile effort to increase its ties with outside scientists, quadrupling to $\$ 80$ million the amount it spends on external, peer-reviewed grants. Although this has earned praise from outside advisory groups and from Congress, the ORD has created a logistical nightmare, says Huggett, in having to handle thousands of new grant proposals.

The National Science Foundation (NSF) has helped EPA to set up review procedures for some of the grants. But Huggett admits that his office is swamped with additional paperwork. One of the new board's first duties will be to help the office to reorganize its peer review procedures.

One solution might be to ask for preproposals, says Huggett. Another is to cooperate with other federal agencies on joint solicitations. He has been meeting the NSF, energy and defence departments and other agencies to help identify opportunities for jointly funded research. A joint solicitation on bio-remediation research with the US Navy, energy department and NSF is expected to go out in October.

Tony Reichhardt

\section{South African minister to quit post}

Cape Town. South Africa's minister responsible for science and technology, Ben Ngubane, is to leave the national cabinet, in which he also holds responsibility for arts and culture, at the end of the month to take up an (as yet unannounced) portfolio in the Kwazulu-Natal provincial cabinet.

Ngubane's move was announced by Mangosuthu Buthelezi, the leader of the Inkatha Freedom Party (IFP), at the party's annual conference last week. Buthelezi is said to have been unhappy about the good working relationship that Ngubane, a physician, enjoys both with his cabinet colleagues and with foreign governments.

President Nelson Mandela appears not to have been consulted. Nor is he understood to have spoken to Ngubane about it since the announcement. Under the terms of the interim constitution, the party is entitled to three cabinet portfolios. But the state president has the prerogative to decide which they should be.

There is little enthusiasm in government circles for the IFP retaining the arts, culture, science and technology portfolio. This is for two reasons. The first is that the department has felt marginalized as a result of having a minister who is not a member of the
African National Congress, the largest party in the coalition government.

The second is that the most likely IFP incumbent to succeed Ngubane is Lionel Mtshali, the party whip. As former education minister in the Kwazulu homeland government, Mtshali enthusiastically implemented a system of patronage under which all officials and teachers employed by his department had to be IFP members.

One alternative is that Mandela might dissolve the ministry, and allocate another portfolio to the IFP. He could then either place the ministry's diverse functions under deputy president Thabo Mbeki, or divide them between existing ministries. If the latter route were to be chosen, science and technology might be allocated to Alec Irwin, the minister of trade and industry, with arts and culture going to Sibusiso Bengu, minister of education.

Ngubane declined to comment on the move, which, ironically, has come just as the ministry seemed to be making real progress after a frustratingly slow start. But his departure is not expected to delay the white paper on science and technology, due to be presented to cabinet later this month, before he leaves his present post.

Michael Cherry

\section{Chemistry professor takes over Islamic science organization}

London. COMSTECH, an intergovernmental organization promoting scientific and technological cooperation within the 50-member Organization of Islamic Countries (OIC), has appointed a new coordinator-general.

Atta ur Rahman, professor of chemistry at the University of Karachi, takes over from M. A. Kazi, science adviser to Pakistan's former military president, General Zia ul Haq. Rahman will remain director of the University of Karachi's H. E. J. Research Institute of Chemistry. The institute carries out research in natural product chemistry, and claims to produce half of Pakistan's annual output of around 50 PhDs.

Rahman has a high profile in his own country as probably the best

known scientist Rahman: will seek to after Abdul Qadeer boost key disciplines.

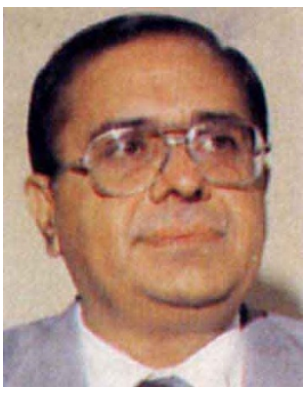

Khan, director of the uranium enrichment laboratory at Kahuta. But he is controversial, having recently announced his institute was close to finding a therapy for AIDS.

Despite convening regular conferences and publishing journals, COMSTECH is viewed as having failed to strengthen research institutions and to promote scientific links between OIC member states.

Rahman says one of his priorities will be to strengthen industrial biotechnology, renewable energy and arid agriculture. Another will be to encourage researchers to make better use of international funding sources. His own institute was recently awarded FFr30 million (US\$6 million) by the French government. He says that COMSTECH's first 13 years can be characterized by "a lack of vision and the naive belief that people will give you money regardless of the quality of your research proposal".

COMSTECH, whose secretariat is based in Islamabad, is one of three OIC science bodies set up in the early 1980s when the organization was awash with Middle Eastern largesse. The other two - the Islamic Scientific, Educational and Cultural Organization, and the Islamic Foundation for Science, Technology and Development - are now less active.

The Pakistan government was keen not to let COMSTECH follow suit and last year gave it a substantial grant for an international conference intended to revive the organization.

Ehsan Masood 